Article

\title{
Divergence Time Estimation of Aloes and Allies (Xanthorrhoeaceae) Based on Three Marker Genes
}

\author{
Zeinab Khodaei ${ }^{1, *(D)}$, Ben-Erik Van Wyk ${ }^{2}$ and Michael Wink ${ }^{1}$ (D) \\ 1 Institute of Pharmacy and Molecular Biotechnology, Heidelberg University, INF 364, 69120 Heidelberg, \\ Germany; wink@uni-hd.de \\ 2 Department of Botany and Plant Biotechnology, University of Johannesburg, P.O. Box 524, \\ Auckland Park 2006, South Africa; bevanwyk@uj.ac.za \\ * Correspondence: zainab.khodaee@googlemail.com; Tel.: +98-912-839-7341
}

Received: 2 January 2018; Accepted: 29 June 2018; Published: 10 July 2018

check for updates

\begin{abstract}
Aloes and allies are prominent members of African succulent vegetation and especially of the highly diverse Cape Flora. The main goal of this study was to obtain age estimates for alooids by calibrating a Bayesian phylogenetic analysis based on two chloroplast markers (the trnL-trnF spacer region and $r b c \mathrm{~L}$ gene) and one gene marker (ITS) using a relaxed molecular clock. Seventy four species from all succulent genera of alooids were analysed with MrBayes to infer species relationships. We discuss the age estimates to address the question whether vicariance or dispersal could account for the diversification of Madagascan alooids. In the combined maximum clade credibility tree obtained from BEAST the succulent alooids have split from asphodeloids around 51.8 Mya in Early Miocene. Divergence time age estimation for succulent drought resistant alooids (late Oligocene to early Miocene) correspond well with dates identified for several other plant lineages in southern Africa and does match with the start of dry period in Miocene which triggered speciation and evolutionary radiation of these genera and families. All climbing aloes and some tree aloes which were recently split into new genera are amongst the early diverged group in alooids and the crown node of this group diverged around 16.82 (15.5-22.4) Mya. The oldest node age estimation for aloes from Madagascar (5.1 Mya) is in early Pliocene and our findings support the hypothesis that the Africa-Madagascan divergence is best explained by oceanic long-distance dispersal rather than vicariance. This study is one of the first to give age estimates for clades of alooids in Xanthorrhoeaceae as a starting point for future studies on the historical biogeography of this family of succulent plants which are important for ethnomedicine, and as ornamental and horticultural plants.
\end{abstract}

Keywords: Xanthorrhoeaceae; alooids; molecular phylogeny; divergence time; rbcL; trnL_F; ITS

\section{Introduction}

Alooids or the subfamily Alooideae sensu )Dahlgren, et al. 1985 ([1] are a well-known group of southern African and Cape rosette leaf succulents (ca. 530 species) adapted to life in dry areas; some members of Aloe occur on the Arabian Peninsula, Madagascar and the Mascarene Islands. Alooids are of interest from an ethnomedical, ornamental and horticultural perspective (Smith et al., 2000) [2]. Aloe ferox is the source of anthraquinones, which are used in medicine as a laxative. Aloe vera is also used as a laxative but also as a gel used for wound-healing, and skin care (van Wyk and Wink, 2017) [3]. In Africa, harvested species of Aloe come from east and southern Africa. During the 1990s, exports of wild-harvested exudate (Aloe) from Kenya sometimes exceeded 80 tons per annum (Oldfield, 2004) [4].

During the last 350 years, this group of plants has seen a number of diverse classifications. At the starting point of modern nomenclature, Linnaeus (1753) [5] had recognised a single genus Aloe to accommodate all aloes and close relatives. Until recently, six genera have been traditionally accepted: 
Aloe L., Astroloba Uitewaal, Gasteria Duval, Haworthia Duval, Chortolirion A. Berger, and Lomatophyllum Willdenow (Smith and Van Wyk, 1998) [6]. Phylogenetic analyses have revealed a high degree of poly- and paraphyly among these genera (Treutlein et al., 2003; Ramdhani et al., 2011; Daru et al., 2012; Manning et al., 2014; Grace et al., 2015) [7-11]. Lomatophyllum, known as berried-aloes, includes around 14 species from Madagascar and some of the Mascarene Islands. This genus has recently been included in the genus Aloe [6]. Manning et al. (2014) [10] have confirmed the paraphyly of the former genus Aloe and suggested to split it into Aloidendron Klopper \& Gideon F.Sm., Kumara Medik., Aloiampelos Klopper \& Gideon F.Sm., Aloe, Aristaloe Boatwr. \& J.C.Manning and Gonialoe (Baker) Boatwr. \& J.C.Manning. The APG IV system (2016) [12] places Aloe and associated genera in the family Asphodelaceae, subfamily Asphodeloideae, one of the three subfamilies of the Xanthorrhoeaceae.

Alooids are characterised by rosulate and succulent leafs and synapomorphies like: Bimodal karyotype with four long and three short chromosomes, hemitropous ovules, a parenchymatous, cap like inner bundle sheath at the phloem poles, 1-methyl-8-hydroxyanthraquinones in the roots and anthrone-C-glycosides in the leaves (Treutlein et al., 2003) [7]. Aloe species are often pollinated by insects and birds but can also be autogamous. Moreover, the widespread occurrence of secondary growth might be added to these characters (Smith and Van Wyk, 1998) [6].

As the largest genus in the Asphodelaceae with approximately 530 species, Aloe has centers of diversity in southern Africa. It occurs widespread in Africa, Arabia, and on several island of the Western Indian Ocean Islands off the east coast of Africa, such as Madagascar, and Socotra (Klopper et al., 2010) [13]. The distribution of Haworthia, Astroloba and Gasteria are similar. The berry fruited Lomatophyllum is limited to Mascarene Islands.

Phylogenetic relationships within alooids have been analysed by sequencing a number of chloroplast and nuclear marker genes. These studies revealed that the genus Aloe, that includes Lomatophyllum, Chortolirion and Haworthia, appeared to be paraphyletic (Treutlein et al., 2003; Ramdhani et al., 2011; Daru et al., 2012; Manning et al., 2014; Grace et al., 2015) [7-11]. The complex generic relationships suggest reticulate evolution and multiple hybridization events (Viljoen, 1999; Ramdhani et al., 2011) [8,14]. Rapid speciation events are especially apparent in the polyphyletic genus Haworthia (Bayer, 1976, 1982, 1999; Treutlein et al., 2003; Ramdhani et al., 2011) [8,15-18].

With regards to species richness alooids are not alone in the Cape Floristic Region (CFR) (Linder et al., 1992; Sauquet et al., 2009) [19,20], which shows a high degree of endemism including $30 \%$ of the succulents plants of the world (Schnitzler et al., 2011) [21]. With the exception of the Karoo flora which diversified as a result of recent radiation during the late Miocene or Pliocene (Verboom et al., 2003 [22], molecular phylogenies indicate that the radiation of several African plant lineages took place over much of the Neogene and had started earlier than the climatic changes in the late Miocene (Bakker et al., 2005; Schrire et al., 2003; Goldblatt et al., 2002) [23-25].

Although representatives of the subfamily Asphodeloideae (including Aloeae) are supposed to have been around since the early Cretaceous (Smith and Van Wyk, 1991) [26], only few dated phylogenies has been published for this diverse complex of succulent plants (Grace et al., 2015) [11].

In the current study, we have analysed nucleotide sequences of 77 taxa, comprising all genera of alooids and three genera of non-succulent Asphodeloids. These data are used to carry out an age estimation for the main clades of alooids (including a diversification of Madagascan aloes), using a "relaxed" molecular clock that permits variation of the molecular rate among lineage in two chloroplast markers ( $t r n L-t r n F$ spacer and $r b c L$ ) and one highly repeated nuclear ITS region. Since there are many different hypotheses including dispersal and extinction or vicariance and peripheral isolation in the speciation process of aloes, we investigated the hypothesis of vicariance vs. dispersal as explanations for the origin of Madagascan aloes. 


\section{Materials and Methods}

\subsection{Taxon Sampling}

Data were compiled for 74 species from all succulent genera of alooids including Lomatophyllum (with three individuals each) and for all of these species new sequences for three gene regions were generated. Only three outgroups were additionally obtained from Genbank for non-succulent genera (asphodeloids which are the sister group of alooids) in the subfamily Asphodeloideae (family Xanthorrhoeaceae). Most of Aloe samples were collected from plants of wild provenance kept in the collection of Gariep Plants in Pretoria. Other genera came from the Botanical Garden of Heidelberg University and the Palmengarten in Frankfurt. Details of GenBank accession numbers and DNA voucher specimens which were deposited at IPMB (Heidelberg University) are presented in Table 1.

Table 1. Origins of samples. List of specimens, distribution of plant samples, morphological information, number in the herbarium of the Institute of Pharmacy and Molecular Biotechnology (IPMB) and GenBank accession numbers (from our own sequence analyses) listed in this order: $r b c L, t r n L \_F$ and ITS. Aloe life forms are according to Carter et al. (2011) [27]: A = grass aloes, $\mathrm{B}=$ maculate aloes, $\mathrm{C}=$ stemless aloes (in small clumps, flower stems few-branched), $\mathrm{D}=$ stemless aloes (in small clumps, flower stems multi-branched), $\mathrm{E}=$ stemless aloes (in large clumps, flower stems few-branched), F = stemless aloes (in large clumps, flower stems multi-branched), $G$ = pendulous or sprawling aloes, $\mathrm{H}=$ shrubby aloes (flower stems few-branched), I = shrubby aloes (flower stems multi-branched), J = tree aloes. Subgeneric classification of Haworthia is based on Bayer (1999) [17]: $\mathrm{HA}=$ subgenus Haworthia, $\mathrm{HE}=$ subgenus Hexangulares and $\mathrm{RO}=$ subgenus Robustipendunculares. Distribution abbreviations: SA = South Africa, Uga = Uganda, Mad = Madagascar, Mal = Malawi, Ken = Kenya, Yem = Yemen, Moz = Mozambique, Zim = Zimbabwe, Tan = Tanzania, Sud = Sudan, Eth = Ethiopia, Som = Somalia, Zam = Zambia, Bot = Botswana, Ang = Angola, Zan = Zanzibar, Swa $=$ Swaziland, Eri $=$ Eritrea, Nam $=$ Namibia, Oma $=$ Oman .

\begin{tabular}{|c|c|c|c|c|}
\hline $\begin{array}{c}\text { IPMB } \\
\text { Number }\end{array}$ & Taxon & Distribution & $\begin{array}{c}\text { Aloe Life Forms \& } \\
\text { Haworthia Subgenera }\end{array}$ & GenBank Accession Numbers \\
\hline P4716 & Aloe arborescens Mill. & SA & $\mathrm{J}$ & KF013362, KF013435, KF013255 \\
\hline P7612 & Aloe aculeata Pole-Evans & SA & $\mathrm{D}$ & KF013363, KF013436, KF013256 \\
\hline P7613 & Aloe africana Mill. & SA & $\mathrm{J}$ & KF013364, KF013437, KF013257 \\
\hline P7615 & Aloe aristata Haw. & SA & $\mathrm{F}$ & AY323634, KF013438, KF013258 \\
\hline P7614 & Aloe amudatensis Reynolds & Uga & B & KF013365, KF013439, KF013259 \\
\hline P7617 & Aloe barberae Dyr. & SA & $\mathrm{J}$ & AJ512294, KF013444, KF013264 \\
\hline P8195 & Aloe bellatula Reynolds & Mad & $\mathrm{E}$ & KF013367, KF013442, KF013262 \\
\hline P7624 & Aloe castellorum J.R.I.Wood & Yem & $\mathrm{C}$ & KF013371, KF013447, KF013267 \\
\hline P8196 & Aloe capitate Baker & Mad & $\mathrm{D}$ & AY323643, KF013448, KF013268 \\
\hline P7628 & Aloe ciliaris Haw. & SA & $\mathrm{H}$ & AJ512287, KF013453, KF013273 \\
\hline P310 & Aloe conifera H. Perrier & Mad & $\mathrm{C}$ & AJ512303, KF013449, KF013269 \\
\hline P7630 & Aloe commixta A. Berger & SA & $\mathrm{H}$ & KF013372, KF013450, KF013270 \\
\hline P7626 & Aloe chabaudii Schönland & Zim & $\mathrm{F}$ & KF013374, KF013452, KF013272, \\
\hline P7632 & Aloe confuse Engl. & Tan & G & KF013375, KF013454, KF013274 \\
\hline P8197 & Aloe deltoideodonta Baker & Mad & C & AJ512304, KF013459, KF013279 \\
\hline P7641 & Aloe elegans Tod. & Eth & $\mathrm{D}$ & KF013381, KF013462, KF013282 \\
\hline P4567 & Aloe ellenbeckii A. Berger & Som & B & KF013378, KF013457, KF013277 \\
\hline P8198 & Aloe erythrophylla Bosser. & Mad & $\mathrm{C}$ & KF013382, KF013463, KF013283 \\
\hline P7642 & Aloe eminens Reynolds \& P.R.O.Bally & Som & $\mathrm{J}$ & KF013384, KF013465, KF013285 \\
\hline P7649 & Aloe fleurentiniorum Lavranos \& L.E. Newton & Yem & $\mathrm{D}$ & KF013388, KF013469, KF013289 \\
\hline P7654 & Aloe grandidentata Salm-Dyck & SA & B & KF013389, KF013470, KF013290 \\
\hline P7653 & Aloe globuligemma Pole-Evans & SA & F & KF013390, KF013471, KF013291 \\
\hline P7657 & Aloe helenae Danguy & Mad & $\mathrm{J}$ & KF013392, KF013473, KF013293 \\
\hline P7658 & Aloe isaloensis H.Perrier & Mad & I & KF013395, KF013476, KF013296 \\
\hline P7659 & Aloe juddii van Jarssv. & SA & $\mathrm{H}$ & KF013396, KF013477, KF013297 \\
\hline P7662 & Aloe kilifiensis Christian & Ken & B & KF013398, KF013480, KF013300 \\
\hline P7661 & Aloe karasbergensis Pillans & SA & $\mathrm{D}$ & AJ522183, KF013481, KF013301 \\
\hline P317 & Aloe lavranosii Reynolds & Yem & $\mathrm{D}$ & AY323647, KF013458, KF013278 \\
\hline P7666 & Aloe macroclada Baker & Mad & C & KF013400, KF013483, KF013303 \\
\hline
\end{tabular}


Table 1. Cont

\begin{tabular}{|c|c|c|c|c|}
\hline $\begin{array}{l}\text { IPMB } \\
\text { Number }\end{array}$ & Taxon & Distribution & $\begin{array}{c}\text { Aloe Life Forms \& } \\
\text { Haworthia Subgenera }\end{array}$ & GenBank Accession Numbers \\
\hline P7669 & Aloe megalacantha Baker & Eth & I & KF013401, KF013484, KF013304 \\
\hline P7668 & Aloe marlothii A.Berger & Bot & $\mathrm{J}$ & KF013402, KF013485, KF013305 \\
\hline P7667 & Aloe maculata All. & SA & B & KF013404, KF013487, KF013307 \\
\hline P7674 & Aloe mudenensis Reynolds. & SA & B & KF013405, KF013488, KF013308 \\
\hline P7675 & Aloe munchii Christian & Zim & $\mathrm{J}$ & KF013406, KF013489, KF013309 \\
\hline P7676 & Aloe mzimbana I.Verd. \& Christian & Mal & $\mathrm{E}$ & KF013407, KF013490, KF013310 \\
\hline P327 & Aloe niebuhriana Lavranos & Yem & E & AY323648, KF013491, KF013311 \\
\hline P7685 & Aloe pillansii L.Guthrie & SA & $\mathrm{J}$ & AJ512292, KF013494, KF013314 \\
\hline P8202 & Aloe parallelifolia H.Perrier & Mad & $\mathrm{H}$ & KF013408, KF013492, KF013312 \\
\hline P8193 & $\begin{array}{c}\text { Aloe prostrata (H.Perrier) L.E.Newton } \mathcal{E} \\
\text { G.D.Rowley }\end{array}$ & Mad & C & KF013361, KF013434, KF013254 \\
\hline P7693 & Aloe retrospiciens Reynolds \& P.R.O.Bally & Som & $\mathrm{J}$ & KF013410, KF013495, KF013315 \\
\hline P7697 & Aloe schweinfurthii Baker & Sud & $\mathrm{F}$ & KF013412, KF013497, KF013317 \\
\hline P7702 & Aloe speciosa Baker & SA & $\mathrm{J}$ & KF013413, HQ646844.1, KF013318 \\
\hline P7703 & Aloe spicata L.f. & SA & $\mathrm{J}$ & KF013414, KF013499, KF013319 \\
\hline P7701 & Aloe somaliensis C.H.Wright ex W.Watson & Som & $\mathrm{D}$ & AY323639, KF013501, KF013501 \\
\hline P331 & Aloe scobinifolia Reynolds \& P.R.O.Bally & Som & $\mathrm{D}$ & AJ512307, KF013502, KF013322 \\
\hline P345 & Aloe sinkatana Reynolds & Sud & $\mathrm{D}$ & AJ512306, KF013503, KF013323 \\
\hline P7705 & Aloe striatula Haw. & SA & $\mathrm{H}$ & KF013415, KF013500, KF013320 \\
\hline P7713 & Aloe tulearensis T.A.McCoy \& Lavranos & Mad & I & KF013420, KF013509, KF013329 \\
\hline P295 & Aloe vera $\mathrm{L}$. & $\begin{array}{l}\text { NEA (North } \\
\text { East Africa) }\end{array}$ & E & AJ290289.1, KF013511, KF013331 \\
\hline P4570 & Aloe viguieri H.Perrier & Mad & G & KF013422, KF013512, KF013332 \\
\hline P7639 & Aloe vryheidensis Groenew. & SA & $\mathrm{J}$ & KF013380, KF013461, KF013281 \\
\hline P7724 & Aloe yemenica J.R.I.Wood & Yem & G & KF013426, KF013516, KF013336 \\
\hline P4635 & Haworthia blackburniae W.F.Barker & SA & HA & AJ512300, HQ646793, KF013337 \\
\hline P8192 & Haworthia cymbiformis Duval & SA & HA & AJ512296, KF013517, KF013338 \\
\hline P4587 & Haworthia mirabilis Haw. & SA & HA & AY323618, KF013518, KF013339 \\
\hline P8189 & Haworthia tortuosa Haw. & SA & HA & KF013427, KF013519, KF013340 \\
\hline P4605 & Haworthia reticulate Haw. & SA & HA & KF013428, KF013520, KF013341 \\
\hline P4565 & Haworthia cooperi Baker & SA & HA & AJ512275, KF013521, KF013342 \\
\hline P8190 & Haworthia truncate Schönland & SA & HA & KF013429, KF013522, KF013343 \\
\hline P4593 & Haworthia gracilis Poelln. & SA & HA & AY323623, KF013523, KF013344 \\
\hline $\mathrm{P} 4604$ & Haworthia fasciata Haw. & SA & $\mathrm{HE}$ & AY323629, HQ646824.1, KF013345 \\
\hline P4599 & Haworthia glauca Baker & SA & $\mathrm{HE}$ & AJ512318, HQ646827.1, KF013346 \\
\hline P8177 & Haworthia coarctata Haw. & SA & $\mathrm{HE}$ & AY323635, KF013524, KF013347 \\
\hline P4582 & Haworthia reinwardtii Haw. & SA & $\mathrm{HE}$ & AY323631, HQ646829.1, KF013348 \\
\hline P8191 & Haworthia venosa Haw. & SA & $\mathrm{HE}$ & KF013430, KF013526, KF013349 \\
\hline P8175 & Haworthia attenuata Haw. & SA & $\mathrm{HE}$ & AJ512315, KF013527, KF013350, \\
\hline $\mathrm{P} 4580$ & Haworthia icosiphylla Baker & SA & & AJ512316, KF013528, KF013351 \\
\hline P6429 & Haworthia minima Baker & SA & $\mathrm{RO}$ & KF013431, HQ646836.1, KF013352 \\
\hline P6427 & Haworthia pumila Duval & SA & $\mathrm{RO}$ & KF013432, HQ646837.1, KF013353, \\
\hline P8173 & Gasteria brevifolia Haw. & SA & & KF013433, KF013529, KF013354 \\
\hline P8172 & Gasteria batesiana G.D.Rowley & SA & & AJ512324, KF013530, KF013355 \\
\hline P4557 & $\begin{array}{c}\text { Gasteria bicolor var. liliputana (Poelln.) van } \\
\text { Jaarsv. }\end{array}$ & SA & & AJ512282, KF013531, KF013356 \\
\hline P306 & Lomatophyllum purpureum T. Durand \& Schinz & SA & & AJ512301, KF013532, KF013357 \\
\hline P4632 & Astroloba foliosa Utiwaal & SA & & AJ512278, KF013534, KF013359 \\
\hline \multirow[t]{3}{*}{ P378 } & Asphodelus aestivus Brot. & SA & & AJ512314, KF013535, KF013360 \\
\hline & Bulbine Wolf & & & AJ512323.1, AJ290294.1, AY323650.1 \\
\hline & Kniphofia uvaria (L.) Hook & & & AJ512330.1, AJ290301.1, EU707283.1 \\
\hline
\end{tabular}

\subsection{Molecular Methods}

DNA was isolated from fresh leaves based on a modified CTAB method (Doyle and Doyle, 1990) [28]. Only the epidermal part of the leaves was used in DNA extraction due to large amounts of secondary metabolites in the mucilaginous part. Extracted DNA was dissolved in TE buffer and the concentration was measured by UV spectrophotometry. 
The $r b c \mathrm{~L}$ region was amplified using primers $r b c \mathrm{~L}-\mathrm{N}$ and $r b c \mathrm{~L}-1 \mathrm{R}$ (reverse). Polymerase chain reaction (PCR) for $r b c \mathrm{~L}$ was carried out using the protocol of Treutlein et al. (2003) [7]. A final volume of $50 \mu \mathrm{L}$ contained $0.5-1 \mu \mathrm{g}$ DNA, $5 \mu \mathrm{L} 10 \times$ PCR buffer, 12.5 pmol primer, $1.5 \mu \mathrm{L}$ dNTPs $(10 \mathrm{mM})$, $0.75 \mathrm{U}$ Taq polymerase, $1 \mu \mathrm{L}$ DMSO and $1 \mu \mathrm{L} 20 \mathrm{mg} / \mathrm{mL}$ BSA. PCR cycle for $r b c \mathrm{~L}$ were $2 \mathrm{~min}$ at $94^{\circ} \mathrm{C}$, then 30 cycles with $45 \mathrm{~s}$ at $94{ }^{\circ} \mathrm{C}, 90 \mathrm{~s}$ at $45^{\circ} \mathrm{C}, 90 \mathrm{~s}$ at $72{ }^{\circ} \mathrm{C}$ and finally 5 min at $72{ }^{\circ} \mathrm{C}$.

The trnL-F spacer was amplified using trnF and E pair primers (Taberlet et al., 1991) [29]. A final volume of $50 \mu \mathrm{L}$ contained 0.5-1 $\mu \mathrm{g}$ DNA, $5 \mu \mathrm{L} 10 \times$ PCR buffer, 12.5 pmol primer, $1.5 \mu \mathrm{L}$ dNTPs $(10 \mathrm{mM}), 0.75 \mathrm{U}$ Taq polymerase and $1 \mu \mathrm{L} 20 \mathrm{mg} / \mathrm{mL}$ BSA. The initial denaturation at $94{ }^{\circ} \mathrm{C}$ for $2 \mathrm{~min}$ was followed by 28 cycles comprising denaturation at $94^{\circ} \mathrm{C}$ for $1 \mathrm{~min}$, annealing at $50{ }^{\circ} \mathrm{C}$ for $1 \mathrm{~min}$ and extension at $72{ }^{\circ} \mathrm{C}$ for $2 \mathrm{~min}$ and a final extension of $7 \mathrm{~min}$ at $72{ }^{\circ} \mathrm{C}$.

The internal transcribed spacer (ITS1 \& 2 and 5.8srDNA) regions were amplified with the primers ITS4 and ITS5 of White, et al. [30] and the same PCR protocol of Adams, et al. [31] with addition of $4 \%$ DMSO to the PCR reaction. The following PCR was applied: 26 cycles of $97^{\circ} \mathrm{C}$ for $1 \mathrm{~min}, 50^{\circ} \mathrm{C}$ for $1 \mathrm{~min}$, and $72{ }^{\circ} \mathrm{C}$ for $3 \mathrm{~min}$, followed by a final extension at $72{ }^{\circ} \mathrm{C}$ for $7 \mathrm{~min}$.

For sequencing, PCR products were precipitated following Gonzalez, et al. [32]. Sequencing was performed using an ABI 3730 automated capillary sequencer (ThermoFisher Scientific, Darmstadt, Germany) with the ABI Prism Big Dye Terminator Cycle Sequencing Ready Reaction Kit version 3.1 and was carried out by STARSEQ GmbH (Mainz, Germany). Accession number of plants and DNA sequences are provided in Table 1.

\subsection{Sequence Editing and Alignment}

Non-coding regions such as trnL_F spacer and ITS are known to contain more substitutions than coding sequences and also carry insertions/deletions (indels). A high occurrence of indel mutations of varying lengths makes sequence alignment problematic (Small et al., 2004) [33]. Because of problems confounding alignment of these regions, all alignments were done manually using BioEdit (Hall, 1999) [34] and gaps corresponding to indels were positioned to minimise the number of nucleotide differences among sequences. To facilitate alignment most of problematic regions in terms of alignment were omitted, which resulted in a fragment of $415 \mathrm{bp}$ for $t r n L \_F$ spacer, $535 \mathrm{bp}$ for ITS region and the final aligned matrix for $r b c \mathrm{~L}$ was $907 \mathrm{bp}$ long. A sequence alignment can be obtained from the first author on request and sequences are deposited in the GenBank (Table 1).

\subsection{Phylogenetic Analyses}

Phylogenetic and molecular evolutionary analyses were conducted using MEGA version 7 (Kumar, et al., 2016) [35]. Phylogenetic reconstruction was performed using maximum likelihood (ML) in MEGA v.7 with the Kimura two-parameter model (Kimura 1980) [36]. MEGA7 was used to estimate the best substitution model: Kimura's two parameter model corrects for multiple hits, taking into account transitional and transversional substitution rates, while assuming that the four nucleotide frequencies are the same and that rates of substitution do not vary among sites. Under a general time reversible nucleotide substitution model (Tavaré, 1986) [37], one thousand inferences were run using among-site rate variation modelled with a gamma distribution. Subsequently, 1000 non-parametric bootstraps were performed under the partition data mode, and bootstrap support values were drawn on the ML tree.

In addition to ML analyses, Bayesian inference (BI) was used implemented in MrBayes v3.2.6 (Ronquist et al., 2012) [38]. To determine the best-fit model of DNA substitution for each loci with Akaike information criterion, MrModeltest v.2.3 [39] was used (for both $r b c L$ and trnL_F: GTR + I + G, and GTR + G for ITS). We used GTR model in MrBayes and BEAST and K2P in MEGA 7 because we wanted to test the consistence between the models. Moreover, K2P is a nested model which is a special case of more general model such as GTR.

Two parallel runs of four chains of the Markov Chain Monte Carlo (MCMC) were executed for 7,000,000 generations, sampled every 1000 generations. 
All parameters were stationary after 500,000 generations. All trees prior to the stationary point were discarded as "burn-in" from the compilation of posterior probabilities (PP). Strongly supported clades have posterior probabilities above 0.90 . Phylogenetic trees were reconstructed for single and combined gene data and visualised using FigTree v1.3.1 [40].

\subsection{Estimating Divergence Times}

The estimates of divergence time of alooids were conducted using combined chloroplast and nuclear datasets.

BEAST v1.8. was used for the Bayesian MCMC inferred analyses of the nucleotide sequence data and BEAUti (Bayesian Evolutionary Analysis Utility) v1.6.1 [41] was utilised to generate initial xml files for BEAST.

A Yule (Yule, 1924) [42] process of speciation ('a pure birth' process) was used as a tree prior for all the tree model analyses and a relaxed uncorrelated log-normal clock (Drummond et al., 2012) [43] in BEAST v1.8. was applied.

Two independent simultaneous runs of 20,000,000 generations were completed, sampling one out of every 1000 trees in BEAST v 1.8. Log files were tested for ESS estimations with Tracer v1.6. (Rambaut \& Drummond 2009) [44], LogCombiner v1.6.1 was used to combine the log files from the independent BEAST runs. Using TreeAnnotator v1.4.8, BEAST trees were summarised with a burn-in value of $25 \%$ and mean node heights (BEAUti, LogCombiner, and TreeAnnotator are all part of the BEAST software bundle).

The calibration mean date for the outgroup of alooids in Xanthorrhoeaceae or the genus Bulbine in Asphodeloids (51 Mya) and the date for the root of Xanthorrhoeaceae (61 Mya) used in the current study were taken from Wikström et al. (2001) [45].

Using fossils as calibration points, the ages and error estimates for over $75 \%$ of all angiosperm families were calculated in these studies, and these estimations were mainly compatible with the fossil record (Wikström et al., 2001) [45]. Moreover, in a recent revision of the age estimation and diversification of angiosperms using BEAST software (Bell et al., 2010) [46] the age estimation for the most cases overlapped the range published by Wikström et al. (2001) [45].

Since the Bayesian methods produce divergence time estimates which are dependent on priors and the model parameters, we tested the impact of using different settings in BEAST and a normal distribution was also applied with the mean value fixed at 61 Mya and a standard deviation of one.

Moreover, we compared our Bayesian estimates with those made using penalised likelihood approach previously applied in Hyacinthaceae, which is also a family in Asparagales, as described by Buerki et al., 2012 [47].

\section{Results}

Phylogenetic trees reconstructed from plastid and nuclear data showed almost identical topologies; therefore, the cpDNA and ncDNA datasets were combined. Partition homogeneity test in PAUP* 4.0 Beta was used and the $P$-value $(P=0.0571)$ indicates a congruency. Maximum Likelihood and MrBayes analyses recovered almost the same phylogenetic relationships for the combined data set. A ML phylogram is shown in Figure 1 and posterior probability values from MrBayes analysis and ML bootstrap numbers are provided at the nodes in this tree.

A BEAST analysis was used to reconstruct phylogeny and to estimate divergence times (Figure 2). The mean ages (with 95\% HPD intervals) are given for the well supported nodes; similar estimates have also been reported in previous phylogenetic studies (Table 2). The mean coefficients of variation $\left(\sigma_{\gamma}\right)$ under the relaxed clock model accounted for more than 1 . This shows that a significant level of rate heterogeneity exists between lineages (Drummond et al., 2007) [48]. The 95\% HPD intervals for the evolutionary root age of the outgroups was similar to those of the study of Wikström et al., (2001) [45]. In the combined maximum clade credibility tree obtained from BEAST, the mean age of the root of the tree for non-succulent asphodeloid members of the subfamily Asphodeloideae is about 51.8 
(47.0-55.5) Mya. The succulent alooids have split from asphodeloids much later around 22.7 (20.3-24.1) Mya in Early Miocene. The result from penalised likelihood method were similar to the BEAST and the two different setting BEAST analyses provided similar values for node age estimates.

The combined dataset resolved four major clades within alooids labelled A-D in Figures 1 and 2: (A) some tree aloes from Aloe sect. Aliodendron, Dracoaloe and all shrubby aloes from Aloe sect. Macrifoliae (B) Haworthia subg. Haworthia, (C) the 'Haworthioid' clades including (C1): Haworthia subg. Robustipedunculares + Astroloba + Poellnitzia + Aloearistata; C2: Haworthia subg. Hexangulares and Gasteria, (D) all other 'true' Aloe species including Lomatophyllum.

(A) Shrubby and Tree aloes: In congruence with previous studies (Treutlein et al., 2003; Ramdhani et al., 2011; Daru et al., 2012) [7-9]. This group is now regarded as a new genus Aloiampelos Klopper \& Gideon F. Sm. (Grace et al., 2015) [11]. Similarly, the tree aloes have been elevated to generic rank, as Aloidendron (A. Berger) Klopper \& Gideon F. Sm. for the species with branched stems and rosulate leaves.

(B) Haworthia subgen. Haworthia: In the present study and in all previous phylogenetic reconstructions (Treutlein et al., 2003; Ramdhani et al., 2011; Daru et al., 2012; Manning et al., 2014) [7-10] these acaulescent Haworthias have always grouped as a monophylum with a high bootstrap and posterior probability values ( $\mathrm{PP}=1 ; \mathrm{BS}=99 \%$ ). Although the mean age of the stem of this monophyletic group is about 12.59 (7.4-16.6) Mya (Table 2), the youngest well supported node amongst all Haworthias can be found in this subgenus with a mean age of about $1.81(0.03-4.5)$ Mya.

(C) Haworthioids: The mean age of the stem node for two other subgenera in Haworthia and other small leaf rosulate taxa (Astroloba and Aloe aristata) is about 13.0 (8.6-17.7) Mya.

(C1) Haworthia subgen. Robustipedunculares, Astroloba and Aloe aristata: This clade displays almost the same topology (posterior probability; PP =1) in the current and most previous studies (Ramdhani et al., 2011; Daru et al., 2012; Manning et al., 2014) [8-10] as a monophyletic sister clade to the other taxa of the subgenus Haworthia and Gasteria (clade C2).

This clade diverged around 9.8 (5.4-13.5) Mya; the divergence time of the well supported monophyletic members of Haworthia subgen. Robustipedunculares is in the late Miocene about 7.78 (3.8-11.4) Mya. These groups have now been raised to generic rank (or reinstated as genera), namely Tulista Raf. (for $H$. subgen. Robustipedunculares) and the monotypic Aristaloe Boatwr. \& J.C. Manning (to accomodate Aloe aristata) (Manning et al., 2014) [10].

(C2) Haworthia subgen. Hexangulares and Gasteria: This clade includes a heterogeneous group of Haworthias from the subgenus Hexangulares which is apparently polyphyletic (Ramdhani et al., 2011; Daru et al., 2012; Manning et al., 2014) [8-10] as a sister clade of a strongly supported monophyletic Gasteria with a weak posterior probability ( $\mathrm{PP}=0.80$; $\mathrm{BS}=60)$. It has diverged around $10.6(5.6-14.8)$ Mya from the other subclade of Haworthioids. The well supported monophyletic Gasteria diverged around 8.9 (4.3-13.2) Mya from Haworthia subgen. Hexangulares, which is now treated as the genus Haworthiopsis G.D. Rowley (Rowley 2013; Manning et al., 2014) [10,49].

(D) True aloes and Lomatophyllum: The rest of the species of aloes including some tree aloes were found to be in one clade (PP = 0.90; BS = 69\%), which diverged about 15.8 (11.5-19.6) Mya. Only some internal groups are possibly monophyletic. For example, most samples from Yemen and North East Africa appeared in a single clade with moderate support value ( $\mathrm{PP}=0.90 ; \mathrm{BS}=59 \%$ ) which has diverged only 4.1 (1.5-6.3) Mya. Moreover, most Madagascan aloes were found in a poorly supported internal clade of aloes with stem node divergence time about 5.3 (2.6-7.2) Mya. Lomatophylum is unlikely to be monophyletic. 


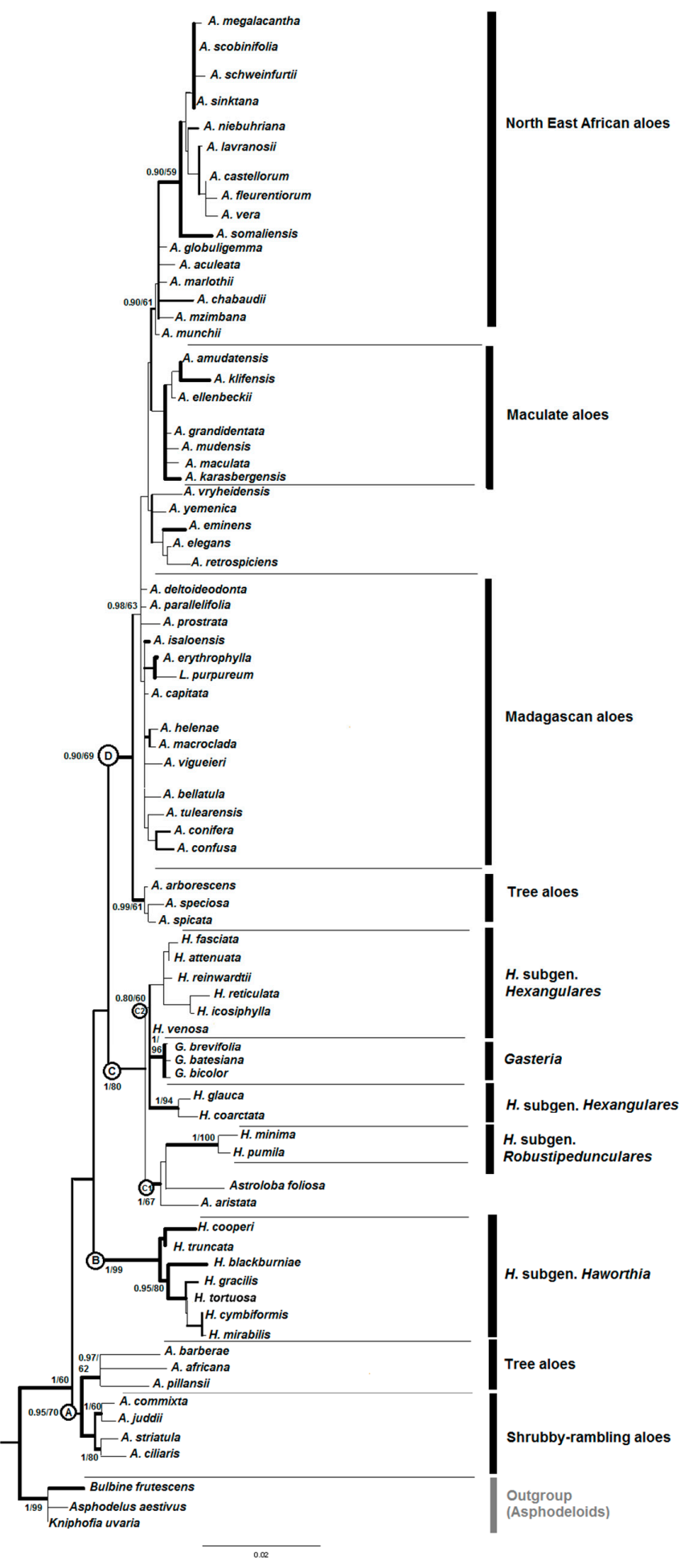

Figure 1. Phylogeny reconstruction of aloes using ML. Numbers at nodes in the ML phylogram refer to posterior probability values from MrBayes and ML bootstrap analyses. The branches in bold indicate a Bayesian posterior probability $>0.95$. Major lineages are highlighted by the letters A to D: (A) Shrubby and Tree aloes, (B) Haworthia subgen. Haworthia, (C) Haworthioids, (C1) Haworthia subgen. Robustipedunculares, Astroloba and Aloe aristata, (C2) Haworthia subgen. Hexangulares and Gasteria, (D) True aloes and Lomatophyllum. 


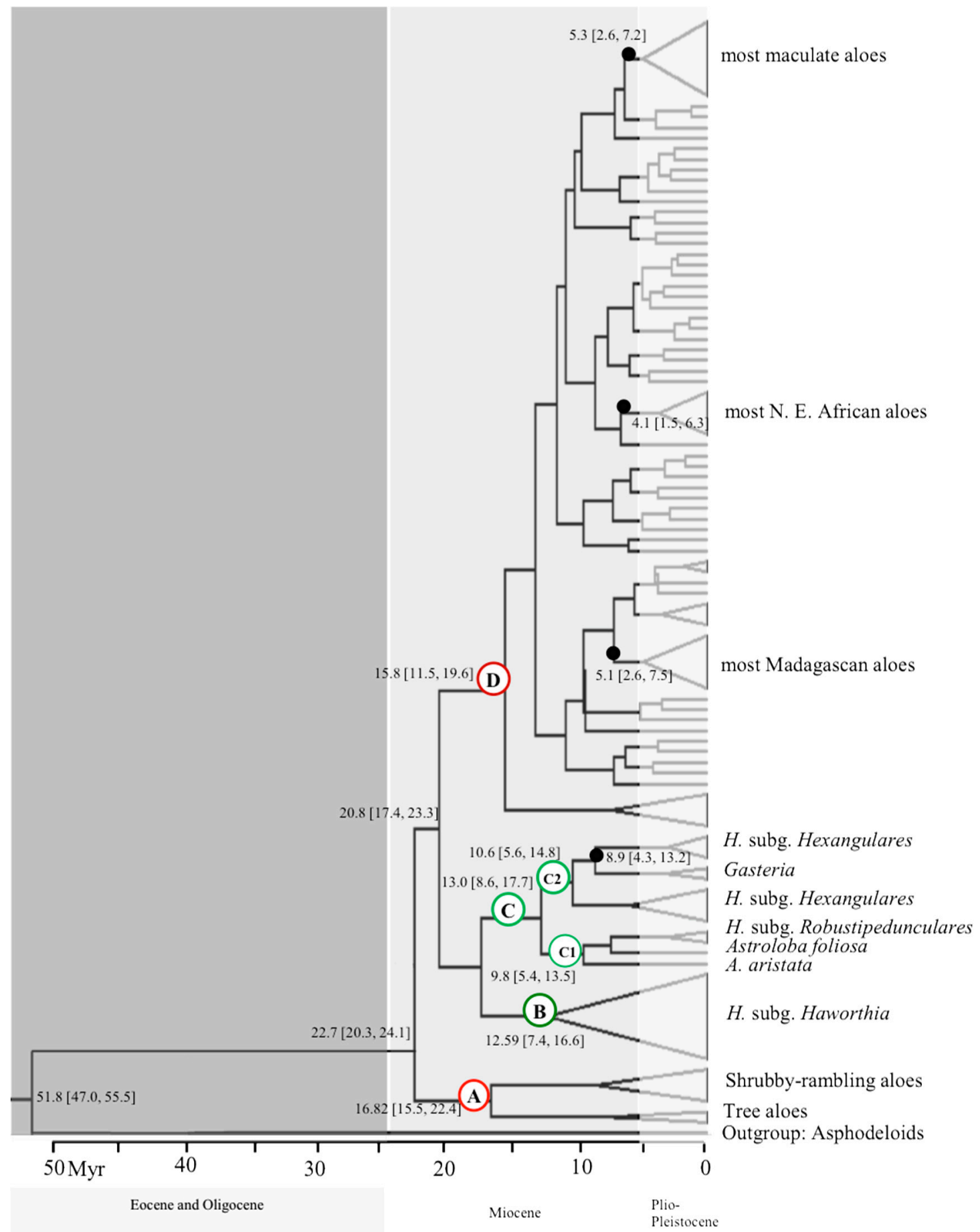

Figure 2. Estimation of divergence times in alooids. The combined maximum clade credibility tree was obtained from BEAST v1.8. Major lineages are highlighted by the letters A to D: (A) Shrubby and Tree aloes, (B) Haworthia subgen. Haworthia, (C) Haworthioids, (C1) Haworthia subgen. Robustipedunculares, Astroloba and Aloe aristata, (C2) Haworthia subgen. Hexangulares and Gasteria, (D) True aloes and Lomatophyllum. 
Table 2. Node age with the posterior probability densities are shown for important clades and outgroups (asphodeloids).

\begin{tabular}{|c|c|c|}
\hline Clades & $\begin{array}{c}\text { Mean Age } \\
\text { (Node, Mya) }\end{array}$ & $\begin{array}{c}\text { 95\% HPD a } \\
\text { (Mya) }\end{array}$ \\
\hline Asphodeloids & 51.8 & $47.0-55.5$ \\
\hline Alooids & 22.7 & $20.3-24.1$ \\
\hline Shrubby and Tree aloes clade A & 16.82 & $15.5-22.4$ \\
\hline Haworthia subgen. Haworthia clade B & 12.59 & $7.4-16.6$ \\
\hline Haworthioid clade $\mathrm{C} 1$ & 9.8 & $5.4-13.5$ \\
\hline Haworthioid clade C2 & 10.6 & $5.6-14.8$ \\
\hline Gasteria & 8.9 & $4.3-13.2$ \\
\hline True aloes \& Lomatophyllum clade D & 15.8 & $11.5-19.6$ \\
\hline Most North East African aloes & 4.1 & $1.5-6.3$ \\
\hline Most Madagascan aloes & 5.1 & $2.6-7.5$ \\
\hline
\end{tabular}

${ }^{a}$ Represent lower-upper 95\% HPD intervals, respectively. The 95\% HPD is regarded as a Bayesian representation of confidence interval.

\section{Discussion}

\subsection{Formation of Arid Habitats in Africa}

A combination of the post African I erosion cycle (5-24 Mya), Post African II uplift event at the Pliocene and the glacial-interglacial cycles in the Pleistocene triggered a rapid speciation of many southern African plants (Siesser, 1978; Goldblatt, 1997) [50,51]. Through the Miocene (5.5-24 Mya) arid habitats became abundant in Africa (Coetzee, 1993; Axelrod and Raven, 1978) [52,53]. In this period falls the divergence of succulent alooids (22.7 Mya), corresponding with the diversification of many other South African lineages such as Iridaceae (Goldblatt and Manning, 2002) [25], Pelargonium (Bakker et al., 2005) [23], and Ehrharta (Verboom et al., 2003) [22].

The mid-Miocene Climatic Optimum (ca. 15 Mya) has led to the development of wide open ecosystems and the start of the radiation of the present hyperdiverse clades of the Cape flora. Moreover, the aridity of Southwestern Africa increased around 14 Mya (Siesser, 1978) [50] through the development of the proto-Benguela current off the coast of SW Africa as a result of the spread of the Antarctic ice sheet. This event led to the radiation of succulent life forms (Goldblatt, 1997) [51], among them alooids.

\subsection{Divergence in Aloes}

An early divergence of shrubby aloes (or their ancestors) around 16.82 (15.5-22.4) Mya had already been suggested by Holland (1978) [54], who had supposed that these succulents represent the original ancient lineage for other aloes during the desertification of Africa.

The early occurrence of fynbos aloes such as Aloe commixta and Aloe juddii (or their ancestors) is in good agreement with the age of many fynbos endemic lineages such as the African Restionaceae (Linder and Hardy, 2004) [55], Moraea (Goldblatt et al., 2002) [56], Muraltia (Forest et al., 2007) [57], Ehrharta (Bouchenak-Khelladi, 2007) [58], Schoeneae (Bremer, 2002) [59], and Zygophyllum (Verboom et al., 2003) [22]. It is remarkable that the divergence of these fire tolerant (Van Wyk and Smith, 2003) [60] rambling aloes agree with the age of the fynbos flora sensu Goldblatt P. and J.C. (2000) [61] in the Early Miocene, ca. 19.5 Mya.

Despite the assumption of an early radiation in southern Africa around the Early Miocene or earlier, most modern African species have radiated in contemporary climatic conditions and have evolved during the Pliocene-Pleistocene (Linder, 1992) [19]. A second Pliocene uplift event in Africa (Partridge and Maud, 2000) [62] caused extensive aridification by changing the ocean currents (Krammer et al., 2006) [63]; this was a period of rapid speciation in many clades such as in Phylica (Richardson et al., 2001) [64], semi-desert ice plants (Aizoaceae) (Klak et al., 2004) [65] and Gladiolus 
(Rymer et al., 2010) [66]. The estimated mean crown age of many nodes within alooids also fall in this period (around $5 \mathrm{Mya}$ ).

From 2.5 Mya (i.e., the Quaternary) onwards, the climatic instability associated with glacial-interglacial cycles in the Northern hemisphere stimulated further diversification in South Africa (Cowling et al., 2009) [67]. The extensive speciation of many plants such as Kniphofia (Bakker et al., 2005) [23] and Haworthia subgen. Haworthia (Bayer, 1999) [17] falls in this period. Although the Haworthias diverged in the mid-Miocene, the youngest internal nodes within alooids are found in this group. This may be considered as further evidence for the recent speciation with in this subgenus of Haworthia as postulated by Ramdhani and co-workers (2011) [8]. The results of Manning et al. (2014) [10] confirm an early separation of the clade.

\subsection{Divergence on Madagascar}

A high diversity of Aloe and Lomatophyllum species was detected on Madagascar which represents the "hottest hotspot" of biodiversity of plants species of the world (Myers et al., 2000) [68]. Only grass aloes have not been found there (Reynolds, 1966) [69]. The oldest node age estimation for aloes from Madagascar (5.1 Mya) is in early Pliocene and apparently much later than the separation of this island during Gondwana from both the mainland of Africa (165-121 Mya) and India (88-63 Mya).

The divergence time of most Madagascan aloes correspond with other greatly diverse plants in Madagascar such as scaly tree ferns (Janssen et al, 2008) [70] and Indian Ocean Daisy Trees (Psiadia) (Strijk et al, 2012) [71]. Due to climatic alternations in the Pliocene (Coetzee, 1993) [52] resulting in habitat disintegration and repetitive decrease and increase of limited forest refugia, it has been assumed that these plants experienced fast geographical parallel diversification spurts in Madagascar. Our findings in aloes support the hypothesis that the Africa-Madagascan divergence is best explained by oceanic long-distance dispersal rather than ancient vicariance.

\subsection{Speciation Processes in Aloes}

Despite the strong influence of climate on plant diversification, it is very unlikely that climate alone is the cause for these levels of plant diversification especially in Cape Flora (Goldblatt and Manning, 2002) [25]. It has been proposed that speciation and endemism in alooids are associated with many other factors. Most species of alooids occur in extremely restricted areas, which are naturally isolated, thus showing a 'mosaic distribution' (Holland, 1978) [54]. It is assumed that specific microclimatic preferences of species had enhanced endemism in aloes (Kamstra, 1971) [72]. Therefore, the drivers of high endemism and speciation of alooids were mainly sought in mechanisms that lead to geographically isolated populations, and so to allopatric speciation (Schluter, 2001) [73]. From several proposed selective forces, a speciation in alooids might have been driven by a change of pollinators as well as by a slight differentiation in flowering times permitting the survival of new forms which enable a greater number of Aloe species to coexist (Rowley, 1976; Botes et al., 2008) [74,75].

In the Cape flora (including Aloe), parapatric sister-species limited to the diverse territories are known as a result of edaphic specialization (Goldblatt et al., 2001; Kurzweil et al., 1991) [76,77], leading to different life forms or ecomorphotypes that are described as different species today (Holland, 1978) [54].

Even though the real biological traits that have influenced speciation of alooids are unclear at this stage, the hypothesis of contemporary speciation and ongoing hybridization (Ramdhani et al. 2011) [8] in non-monophyletic genera of alooids (such as Haworthia sensu lato) should also be considered as an explanation for the complex taxonomy and the abundance of habitat restricted species.

\section{Conclusions}

In conclusion, although age estimations are dependent on fossil calibrations and monocots do not fossilise well, we hope that this phylogenetic study of alooids, in which we aimed to sample most sections of Aloe and many of its allied genera, will throw light on the causes of the high 
diversity in alooids and the timing of their speciation. We suggest that future studies focus on increased taxon sampling to conclude more comprehensive age estimates for this important group of African succulents.

Author Contributions: M.W. and Z.K. conceived and designed the experiments; Z.K. performed the experiments and analysed the data; M.W. and B.-E.V.W. contributed materials/analysis tools and revised the ms; Z.K. wrote the paper.

Funding: DAAD funded a PhD fellowship of Z.K.

Acknowledgments: Z.K. thanks the DAAD for a PhD fellowship.

Conflicts of Interest: The authors declare no conflict of interest. The founding sponsors had no role in the design of the study; in the collection, analyses, or interpretation of data; in the writing of the manuscript, and in the decision to publish the results.

\section{References}

1. Dahlgren, R.M.T.; Clifford, H.T.; Yeo, P.F. The Families of the Monocotyledons: Structure, Evolution, and Taxonomy; Springer: Berlin, Germany, 1985.

2. Smith, G.F.; Steyn, E.M.A.; Victor, J.E.; Crouch, N.R.; Golding, J.; Hilton-Taylor, C. The conservation status of Aloe in South Africa: An updated synopsis. Bothalia 2000, 30, 206-211.

3. Van Wyk, B.-E.; Wink, M. Medicinal Plants of the World, 2nd ed.; CABI: Wallingford, UK, 2017.

4. Oldfield, S.A. Review of significant trade: East African Aloes. In Document 9.2.2, Annex 4, Proceedings of the 14th Meeting of the CITES Plants Committee, Windhoek Namibia, 16-20 February 2004; Convention on International Trade in Endangered Species of Wild Fauna and Flora (CITES): Geneva, Switzerland, 2004.

5. Linnaeus, C. Species Plantarum 1; Laurentius Salvius: Stockholm, Sweden, 1753; p. 319.

6. Smith, G.F.; Van Wyk, B.-E. Asphodelaceae. In The Families and Genera of Vascular Plants 3. Monocotyledons. Lilianae (except Orchidaceae); Kubitzki, K., Ed.; Springer: Berlin, Germany, 1998; pp. 130-140.

7. Treutlein, J.; Smith, G.F.; van Wyk, B.E.; Wink, M. Phylogenetic relationships in Asphodelaceae (subfamily Alooideae) inferred from chloroplast DNA sequences $(r b c \mathrm{~L}, m a t \mathrm{~K})$ and from genomic fingerprinting (ISSR). Taxon 2003, 52, 193-207. [CrossRef]

8. Ramdhani, S.; Barker, N.P.; Cowling, R.M. Revisiting monophyly in Haworthia Duval (Asphodelaceae): Incongruence, hybridization and contemporary speciation. Taxon 2011, 60, 1001-1014.

9. Daru, B.H.; Manning, J.C.; Boatwright, J.S.; Maurin, O.; Maclean, N.; Schaefer, H.; Kuzmina, M.; van der Bank, M. Molecular and morphological analysis of subfamily Alooideae (Asphodelaceae) and the inclusion of Chortolirion in Aloe. Taxon 2012, 62, 62-76.

10. Manning, J.; Boatwright, J.S.; Daru, B.H.; Maurin, O.; van der Bank, M. A molecular phylogeny and generic classification of Asphodelaceae subfamily Alooideae: A final resolution of the prickly issue of polyphyly in the Alooids? Syst. Bot. 2014, 39, 55-74. [CrossRef]

11. Grace, O.M.; Buerki, S.; Symonds, M.R.; Forest, F.; van Wyk, A.E.; Smith, G.F.; Klopper, R.R.; Bjorå, C.S.; Neale, S.; Demissew, S.; et al. Evolutionary history and leaf succulence as explanations for medicinal use in aloes and the global popularity of Aloe vera. BMC Evol. Biol. 2015. [CrossRef] [PubMed]

12. The Angiosperm Phylogeny Group; Chase, M.W.; Christenhusz, M.J.M.; Fay, M.F.; Byng, J.W.; Judd, W.S.; Soltis, D.E.; Mabberley, D.J.; Sennikov, A.N.; Soltis, P.S.; et al. An update of the Angiosperm Phylogeny Group classification for the orders and families of flowering plants: APG IV. Bot. J. Linn. Soc. 2016, 181, 1-20.

13. Klopper, R.R.; van Wyk, A.E.; Smith, G.F. Phylogenetic relationships in the family Asphodelaceae (Asparagales). Biodivers. Ecol. 2010, 3, 9-36.

14. Viljoen, A.M. Chemotaxonomic Study of Phenolic Leaf Compounds in the Genus Aloe; Rand Afrikaans University (now University of Johannesburg): Johannesburg, South Africa, 1999.

15. Bayer, M.B. Haworthia Handbook; Kirstenbosch National Botanic Gardens: Cape Town, South Africa, 1976.

16. Bayer, M.B. The New Haworthia Handbook; Kirstenbosch National Botanic Gardens: Cape Town, South Africa, 1982.

17. Bayer, M.B. Haworthia Revisited: A Revision of the Genus; Umdaus Press: Hatfield, UK, 1999. 
18. Treutlein, J.; Smith, G.F.; van Wyl, B.E.; Wink, M. Evidence for the polyphyly of Haworthia (Asphodelaceae subfamily Alooideae; Asparagales) inferred from nucleotide sequences of $r b c \mathrm{~L}$, matK, ITS1 and genomic fingerprinting with ISSR-PCR. Plant Biol. 2003, 5, 513-521. [CrossRef]

19. Linder, H.P.; Meadows, M.E.; Cowling, R.M. The ecology of fynbos: Nutrients, fire and diversity. In History of the Cape Flora; Cowling, R.M., Ed.; Oxford University Press: Oxford, UK, 1992; pp. 113-134.

20. Sauquet, H.; Weston, P.H.; Anderson, C.L.; Barker, N.P.; Cantrill, D.J.; Mast, A.R.; Savolainen, V. Contrasted patterns of hyperdiversification in Mediterranean hotspots. Proc. Natl. Acad. Sci. USA 2009, 106, 221-225. [CrossRef] [PubMed]

21. Schnitzler, J.; Barraclough, T.G.; Boatwright, J.S.; Goldblatt, P.; Manning, J.C.; Powell, M.P.; Rebelo, T.; Savolainen, V. Causes of plant diversification in the Cape biodiversity hotspot of South Africa. Syst. Biol. 2011, 60, 343-357. [CrossRef] [PubMed]

22. Verboom, G.A.; Linder, H.P.; Stock, W.D. Phylogenetics of the grass genus Ehrharta: Evidence for radiation in the summer-arid zone of the South African Cape. Evolution 2003, 57, 1008-1021. [CrossRef] [PubMed]

23. Bakker, F.T.; Culham, A.; Marais, E.; Gibby, M. Nested radiation in Cape Pelargonium. In Plant Species-Level Systematics: New Perspectives on Pattern E Process; Bakker, F.T., Chatrou, L.W., Gravendeel, B., Pelser, P.B., Eds.; Koeltz: Königstein, Germany, 2005; pp. 75-100.

24. Schrire, B.D.; Lavin, M.; Barker, N.P.; Cortes-Burns, H.; von Senger, I.; Kim, J.-H. Towards a phylogeny of Indigofera (Leguminosae-Papilionoideae): Identification of major clades and relative ages. In Advances in Legume Systematics, Part 10, Higher Level Systematics; Klitgaard, B.B., Bruneau, A., Eds.; Royal Botanic Gardens, Kew: London, UK, 2003; pp. 269-302.

25. Goldblatt, P.; Manning, J.C. Plant diversity of the Cape region of southern Africa. Ann. MO. Bot. Gard. 2002, 89, 281-302. [CrossRef]

26. Smith, G.F.; van Wyk, B.-E. Generic relationships in the Alooideae (Asphodelaceae). Taxon 1991, 40, 557-581. [CrossRef]

27. Carter, S.; Lavranos, J.J.; Newton, L.E.; Walker, C.C. Aloes: The Definitive Guide; Kew Publishing, Royal Botanic Gardens Kew: London, UK, 2011.

28. Doyle, J.J.; Doyle, J.L. Isolation of plant DNA from fresh tissue. Focus 1990, 12, 13-15.

29. Taberlet, P.; Gielly, L.; Patou, G.; Bouvet, J. Universal primers for amplification of three noncoding regions of chloroplast DNA. Plant Mol. Biol. 1991, 17, 1105-1109. [CrossRef] [PubMed]

30. White, T.J.; Bruns, T.D.; Lee, S.; Taylor, J. Amplification and direct sequencing of fungal ribosomal RNA genes for phylogenetics. In PCR Protocols, a Guide to Methods and Applications; Innis, M.A., Gelfand, D.H., Sninsky, J.J., White, T.J., Eds.; Academic Press: San Diego, CA, USA, 1990; pp. 315-322.

31. Adams, S.P.; Leitch, I.J.; Bennett, M.D.; Chase, M.W.; Leitch, A.R. Ribosomal DNA evolution and phylogeny in Aloe (Asphodelaceae). Am. J. Bot. 2000, 87, 1578-1583. [CrossRef] [PubMed]

32. Gonzalez, J.; Wink, M.; Garcia-del-Rey, E.; Delgado, G. Evidence from DNA nucleotide sequences and ISSR profiles indicates paraphyly in subspecies of the Southern Grey Shrike (Lanius meridionalis). J. Ornithol. 2008, 149, 495-506. [CrossRef]

33. Small, R.; Cronn, R.; Wendel, J. Use of nuclear genes for phylogeny reconstruction in plants. Aust. Syst. Bot. 2004, 17, 145-170. [CrossRef]

34. Hall, T.A. BioEdit: A user-friendly biological sequence alignment editor and analysis. In Nucleic Acids Symposium Series; Information Retrieval Ltd.: London, UK, 1999.

35. Kumar, S.; Stecher, G.; Tamura, K. MEGA7: Molecular Evolutionary Genetics Analysis version 7.0 for bigger datasets. Mol. Biol. Evol. 2016, 33, 1870-1874. [CrossRef] [PubMed]

36. Kimura, M. A simple method for estimating evolutionary rates of base substitutions through comparative studies of nucleotide sequences. J. Mol. Evol. 1980, 16, 111-120. [CrossRef] [PubMed]

37. Tavaré, S. Some probabilistic and statistical problems in the analysis of DNA sequences. In Some Mathematical Questions in Biology: DNA Sequence Analysis; Waterman, M.S., Ed.; American Mathematical Society: Providence, RI, USA, 1986; pp. 57-86.

38. Ronquist, F.; Teslenko, M.; van der Mark, P.; Ayres, D.L.; Darling, A.; Höhna, S.; Larget, B.; Liu, L.; Suchard, M.A.; Huelsenbeck, J.P. MrBayes 3.2: Efficient Bayesian phylogenetic inference and model choice across a large model space. Syst. Biol. 2012, 61, 539-542. [CrossRef] [PubMed]

39. Nylander, J.A.A. MrModeltest: Program Distributed by the Author; Evolutionary Biology Centre, Uppsala University: Uppsala, Sweden, 2004. 
40. Rambaut, A. FigTree v1.2.3; Institute of Evolutionary Biology, University of Edinburgh: Edinburgh, UK, 2009.

41. Drummond, A.; Rambaut, A.; Xie, W. (2002-2010) BEAUTI-Bayesian Evolutionary Analysis Utility Version v1.6.1. Available online: http:/ / beast.bio.ed.ac.uk (accessed on 31 May 2012).

42. Yule, G.U. A mathematical theory of evolution, based on the conclusions of Dr. JC Wills, FRS. Philos. Trans. R. Soc. Lond. Ser. B 1924, 213, 21-87. [CrossRef]

43. Drummond, A.J.; Suchard, M.A.; Xie, D.; Rambaut, A. Bayesian phylogenetics with BEAUti and the BEAST 1.7. Mol. Biol. Evol. 2012, 29, 1969-1973. [CrossRef] [PubMed]

44. Rambaut, A.; Drummond, A.J. Tracer: Version 1.5. Available online: http://beast.bio.ed.ac.uk/Tracer (accessed on 31 May 2012).

45. Wikström, N.; Savolainen, V.; Chase, M.W. Evolution of the angiosperms: Calibrating the family tree. Proc. R. Soc. Lond. 2001, 268, 2211-2220. [CrossRef] [PubMed]

46. Bell, C.; Soltis, D.; Soltis, P. The age and diversification of the angiosperms re-revisited. Am. J. Bot. 2010, 97 , 1296-1303. [CrossRef] [PubMed]

47. Buerki, S.; Jose, S.; Yadav, S.R.; Goldblatt, P.; Manning, J.C.; Forest, F. Contrasting biogeographic and diversification patterns in two Mediterranean-type ecosystems. PLoS ONE 2012, 7, e39377. [CrossRef] [PubMed]

48. Drummond, A.; Ho, S.; Rawlence, N.; Rambaut, A. A Rough Guide to BEAST 1.4; BEAST Version 1.61 Manual; University of Edinburgh: Edinburgh, Scotland, 2007.

49. Rowley, G.D. Generic concepts in the Alooideae 3: The phylogenetic story. Alsterworth. Int. Spec. Issue 2013, $10,1-7$.

50. Siesser, W.G. Aridification of the Namib Desert: Evidence from oceanic cores. In Antarctic Glacial History and World Palaeoenvironments; van Zinderen Bakker, E.M., Ed.; Balkema: Rotterdam, the Netherlands, 1978; pp. 105-113.

51. Goldblatt, P. Floristic diversity in the Cape flora of South Africa. Biodivers. Conserv. 1997, 6, 359-377. [CrossRef]

52. Coetzee, J. African flora since the terminal Jurassic. In Biological Relationships between Africa and South America; Goldblatt, P., Ed.; Yale University Press: New Haven, CT, USA, 1993; pp. 37-61.

53. Axelrod, D.I.; Raven, P.H. Late Cretaceous and Tertiary vegetation history of Africa. In Biogeography and Ecology of southern Africa; Werger, M.J.A., Ed.; Junk: The Hague, The Netherlands, 1978.

54. Holland, P.G. An evolutionary biogeography of the genus Aloe. J. Biogeogr. 1978, 5, 213-226. [CrossRef]

55. Linder, H.P.; Hardy, C.R. Evolution of the species-rich Cape flora. Philos. Trans. R. Soc. Lond. B Biol. Sci. 2004, 359, 1623-1632. [CrossRef] [PubMed]

56. Goldblatt, P.; Savolainen, V.; Porteous, O.; Sostaric, I.; Powell, M.; Reeves, G.; Manning, J.C.; Barraclough, T.G.; Chase, M.W. Radiation in the Cape flora and the phylogeny of peacock irises Moraea (Iridaceae) based on flour plastid DNA regions. Mol. Phylogenet. Evol. 2002, 25, 341-360. [CrossRef]

57. Forest, F.; Nänni, I.; Chase, M.W.; Crane, P.R.; Hawkins, J.A. Diversification of a large genus in a continental biodiversity hotspot: Temporal and spatial origin of Muraltia (Polygalaceae) in the Cape of South Africa. Mol. Phylogenet. Evol. 2007, 43, 60-74. [CrossRef] [PubMed]

58. Bouchenak-Khelladi, Y. Grass evolution and diversification: A phylogenetic approach. Ph.D. Thesis, University of Dublin, Dublin, Ireland, 2007.

59. Bremer, K. Gondwanan evolution of the grass alliance of families (Poales). Evolution 2002, 56, $1374-1387$. [CrossRef] [PubMed]

60. Van Wyk, B.E.; Smith, G.F. Guide to aloes of South Africa; Briza Publications: Pretoria, South Africa, 2003.

61. Goldblatt, P.; Manning, J.C. New species of Moraea (Iridaceae-Iridoideae) from southern Africa. Novon 2000, 10, 14-21. [CrossRef]

62. Partridge, T.C.; Maud, R.R. Macro-scale geomorphic evolution of Southern Africa. In The Cenozoic of Southern Africa; Partridge, T.C., Maud, V., Eds.; Oxford University Press: Oxford, UK, 2000; pp. 3-18.

63. Krammer, R.; Baumann, K.H.; Hennich, R. Middle to late Miocene fluctuations in the incipient Benguela Upwelling System revealed by calcareous nannofossil assemblages. Palaeogeogr. Palaeoclimatol. Palaeoecol. 2006, 230, 319-334. [CrossRef]

64. Richardson, J.E.; Pennington, R.T.; Pennington, T.D.; Hollingsworth, P.M. Rapid diversification of a species-rich genus of neotropical rain forest trees. Science 2001, 293, 2242-2245. [CrossRef] [PubMed] 
65. Klak, C.; Reeves, G.; Hedderson, T.A. Unmatched tempo of evolution in Southern African semi-desert ice plants. Nature 2004, 427, 63-65. [CrossRef] [PubMed]

66. Rymer, P.; Manning, J.; Goldblatt, P.; Powell, M.; Savolainen, V. Evidence of recent and continuous speciation in a biodiversity hotspot: A population genetic approach in southern African gladioli (Gladiolus; Iridaceae). Mol. Ecol. 2010, 19, 4765-4782. [CrossRef] [PubMed]

67. Cowling, R.M.; Procheş, Ş.; Partridge, T.C. Explaining the uniqueness of the Cape flora: Incorporating geomorphic evolution as a factor for explaining its diversification. Mol. Phylogenet. Evol. 2009, 51, 64-74. [CrossRef] [PubMed]

68. Myers, N.; Mittermeier, R.A.; Mittermeier, C.G.; da Fonseca, G.A.B.; Kent, J. Biodiversity hotspots for conservation priorities. Nature 2000, 403, 853-858. [CrossRef] [PubMed]

69. Reynolds, G.W. The Aloes of Tropical Africa and Madagascar; The Aloes Book Fund: Mbabane, Swaziland, 1966.

70. Janssen, T.; Bystriakova, N.; Rakotondrainibe, F.; Coomes, D.; Labat, J.N.; Schneider, H. Neoendemism in Madagascan Scaly Tree Ferns results from recent coincident diversification bursts. Evolution 2008, 62, 1876-1889. [CrossRef] [PubMed]

71. Strijk, J.S.; Noyes, R.D.; Strasberg, D.; Cruaud, C.; Gavory, F.; Chase, M.W.; Abbott, R.J.; Thebaud, C. Correction: In and out of Madagascar: Dispersal to peripheral islands, insular speciation and diversification of Indian Ocean Daisy Trees (Psiadia, Asteraceae). PLoS ONE 2013, 8. [CrossRef]

72. Kamstra, M.W. Aloe seeds. Excelsa 1971, 1, 19-26.

73. Schluter, D. Ecology and the origin of species. Trends Ecol. Evol. 2001, 16, 372-380. [CrossRef]

74. Rowley, G.D. Generic concepts in the Aloineae. Natl. Cactus Succul. J. 1976, 31, 26.

75. Botes, C.; Johnson, S.D.; Cowling, R.M. Coexistence of succulent tree aloes: Partitioning of bird pollinators by floral traits and flowering phenology. Oikos 2008, 117, 875-882. [CrossRef]

76. Goldblatt, P.; Manning, J.; Bernhardt, P. Radiation of pollination systems in Gladiolus (Iridaceae: Crocoideae) in Southern Africa. Ann. MO. Bot. Gard. 2001, 88, 713-734. [CrossRef]

77. Kurzweil, H.; Linder, H.P.; Chesselet, P. Phylogeny and evolution of the Pterygodium-Corycium complex. Plant Syst. Evol. 1991, 175, 161-223. [CrossRef]

(C) 2018 by the authors. Licensee MDPI, Basel, Switzerland. This article is an open access article distributed under the terms and conditions of the Creative Commons Attribution (CC BY) license (http://creativecommons.org/licenses/by/4.0/). 